\title{
Surgery Milestones
}

The Accreditation Council for Graduate Medical Education

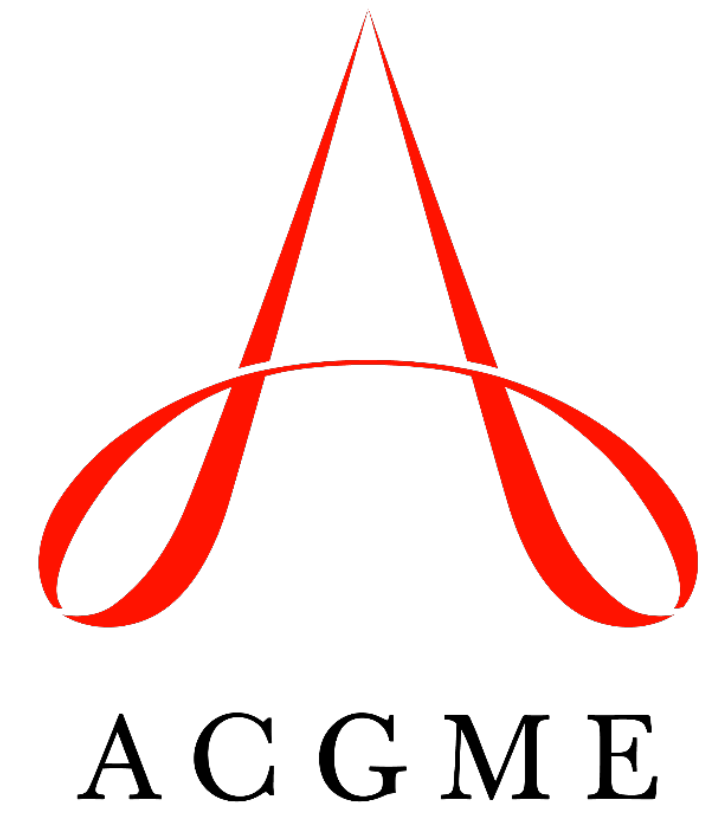

Second Revision: January 2019

First Revision: December 2013 


\section{Surgery Milestones}

The Milestones are designed only for use in evaluation of residents in the context of their participation in ACGME-accredited residency programs. The Milestones provide a framework for the assessment of the development of the resident in key dimensions of the elements of physician competency in a specialty or subspecialty. They neither represent the entirety of the dimensions of the six domains of physician competency, nor are they designed to be relevant in any other context. 


\section{Surgery Milestones}

\section{Work Group}

Karen Brasel, MD, MPH

Wade Douglas, MD

Laura Edgar, EdD, CAE

Kenneth Gow, MD

Donna Lamb, DHSc, MBA, BSN

Pamela Lipsett, MD, MHPE

Mark Malangoni, MD

Shari Meyerson, MD
M. Timothy Nelson, MD

Chris Pfeifer, DO

David Rubenstein, FACHE

Edward Shipper, MD

Gainosuke Sugiyama, MD

Danny Takanishi Jr., MD

Richard Thirlby, MD

Albert Yurvati, DO, PhD

The ACGME would like to thank the following organizations for their continued support in the development of the Milestones:

American Board of Surgery

American Osteopathic Board of Surgery

Association of Program Directors in Surgery

Review Committee for Surgery

Association of American Medical Colleges

American Association of Colleges of Osteopathic Medicine 


\section{Understanding Milestone Levels and Reporting}

This document presents the Milestones, which programs use in a semi-annual review of resident performance, and then report to the ACGME. Milestones are knowledge, skills, attitudes, and other attributes for each of the ACGME Competencies organized in a developmental framework. The narrative descriptions are targets for resident performance throughout their educational program.

Milestones are arranged into levels. Tracking from Level 1 to Level 5 is synonymous with moving from novice to expert resident in the specialty or subspecialty. For each reporting period, the Clinical Competency Committee will review the completed evaluations to select the milestone levels that best describe each learner's current performance, abilities, and attributes for each subcompetency.

These levels do not correspond with post-graduate year of education. Depending on previous experience, a junior resident may achieve higher levels early in his/her educational program just as a senior resident may be at a lower level later in his/her educational program. There is no predetermined timing for a resident to attain any particular level. Residents may also regress in achievement of their milestones. This may happen for many reasons, such as over scoring in a previous review, a disjointed experience in a particular procedure, or a significant act by the resident.

Selection of a level implies the resident substantially demonstrates the milestones in that level, as well as those in lower levels (see the diagram on page $v$ ). 


\section{Additional Notes}

Level 4 is designed as a graduation goal but does not represent a graduation requirement. Making decisions about readiness for graduation and unsupervised practice is the purview of the program director. Furthermore, Milestones 2.0 include revisions and changes that preclude using Milestones as a sole assessment in high-stakes decisions (i.e., determination of eligibility for certification or credentialing). Level 5 is designed to represent an expert resident whose achievements in a subcompetency are greater than the expectation. Milestones are primarily designed for formative, developmental purposes to support continuous quality improvement for individual learners, education programs, and the specialty. The ACGME and its partners will continue to evaluate and perform research on the Milestones to assess their impact and value.

Examples are provided for some milestones within this document. Please note: the examples are not the required element or outcome; they are provided as a way to share the intent of the element.

Some milestone descriptions include statements about performing independently. These activities must occur in conformity to ACGME supervision guidelines as described in the Program Requirements, as well as to institutional and program policies. For example, a resident who performs a procedure independently must, at a minimum, be supervised through oversight.

A Supplemental Guide is also available to provide the intent of each subcompetency, examples for each level, assessment methods or tools, and other available resources. The Supplemental Guide, like examples contained within the Milestones, is designed only to assist the program director and Clinical Competency Committee, and is not meant to demonstrate any required element or outcome.

Additional resources are available in the Milestones section of the ACGME website. Follow the links under "What We Do" at www.acgme.org. 
The diagram below presents an example set of milestones for one sub-competency in the same format as the ACGME Report Worksheet. For each reporting period, a resident's performance on the milestones for each sub-competency will be indicated by selecting the level of milestones that best describes that resident's performance in relation to those milestones.

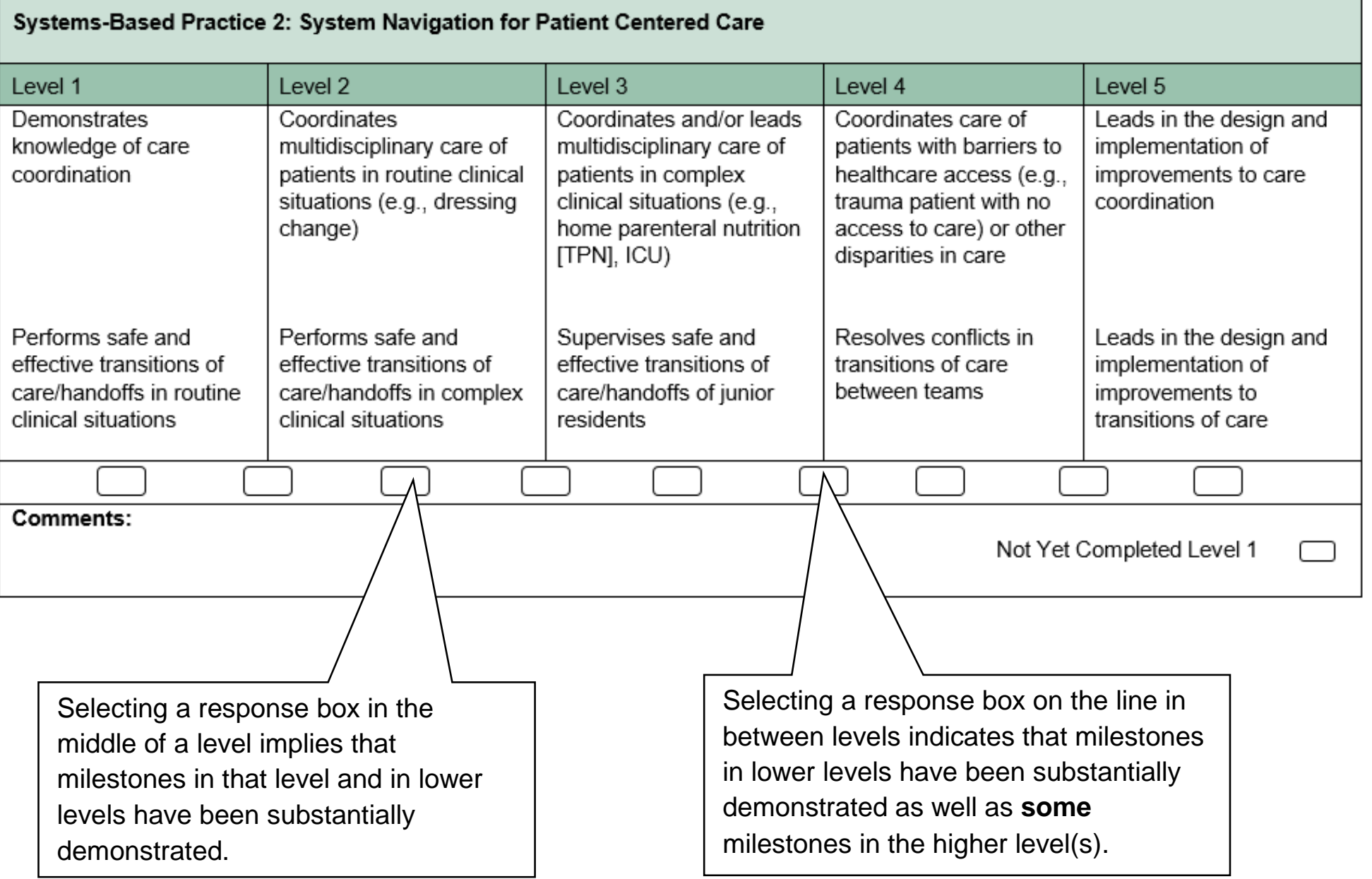




\section{Patient Care 1: Patient Evaluation and Decision Making}

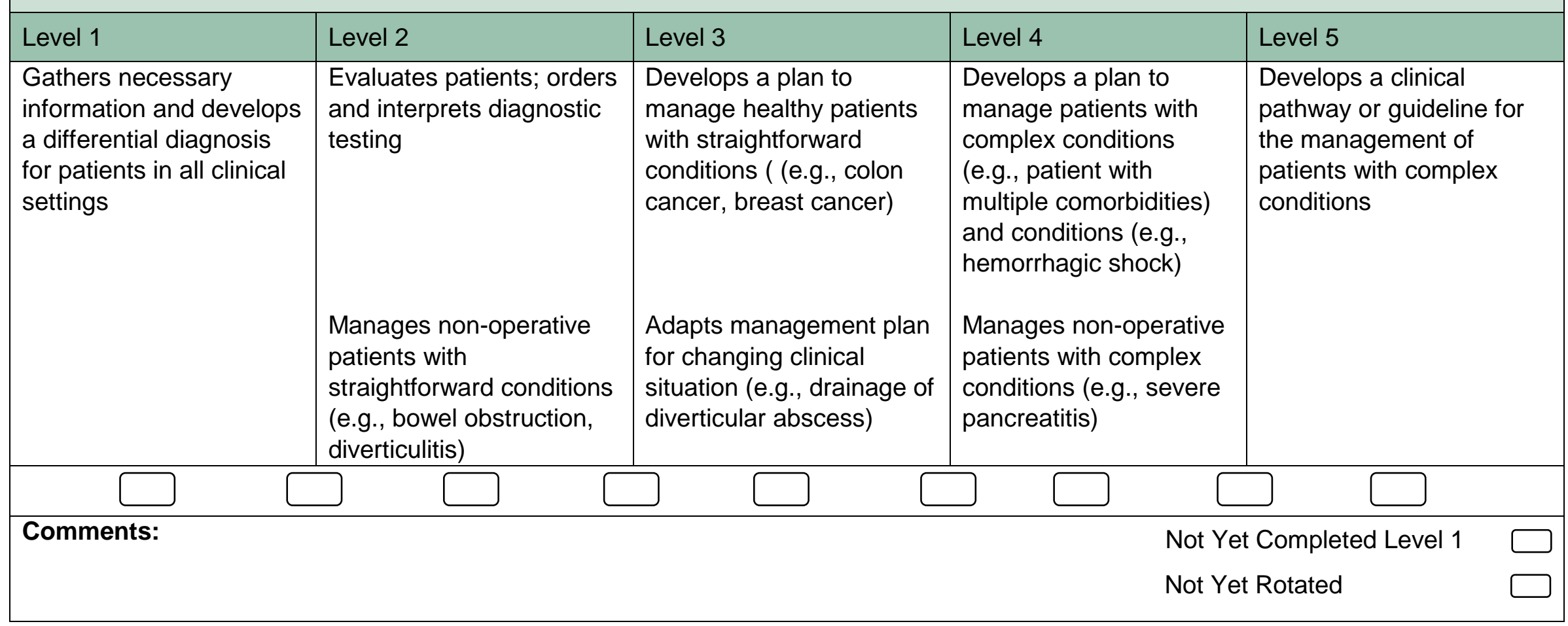




\section{Patient Care 2: Intra-Operative Patient Care - Performance of Procedures}

\begin{tabular}{|c|c|c|c|c|}
\hline Level 1 & Level 2 & Level 3 & Level 4 & Level 5 \\
\hline $\begin{array}{l}\text { Demonstrates basic } \\
\text { skills (e.g., knot tying, } \\
\text { suturing) }\end{array}$ & $\begin{array}{l}\text { Performs bedside } \\
\text { procedures (e.g., central } \\
\text { line, chest tube) } \\
\text { Teaches basic skills to } \\
\text { medical students and } \\
\text { junior residents }\end{array}$ & $\begin{array}{l}\text { Performs common } \\
\text { operations (e.g., hernia, } \\
\text { cholecystectomy, } \\
\text { appendectomy) } \\
\text { Teaches bedside } \\
\text { operations to junior } \\
\text { residents }\end{array}$ & $\begin{array}{l}\text { Performs complex } \\
\text { operations (e.g., low } \\
\text { anterior resection, } \\
\text { paraesophegeal hernia, } \\
\text { abdominal wall } \\
\text { reconstruction) } \\
\text { Teaches common } \\
\text { operations to junior } \\
\text { residents }\end{array}$ & $\begin{array}{l}\text { Performs uncommon } \\
\text { complex operations (e.g., } \\
\text { Whipple, esophagectomy) } \\
\text { Teaches complex } \\
\text { operations to junior } \\
\text { residents }\end{array}$ \\
\hline Comments: & & & $\begin{array}{l}\text { Not Yet } \\
\text { Not Yet }\end{array}$ & $\begin{array}{l}\text { ompleted Level } 1 \\
\text { otated }\end{array}$ \\
\hline
\end{tabular}




\section{Patient Care 3: Intra-Operative Patient Care - Technical Skills}

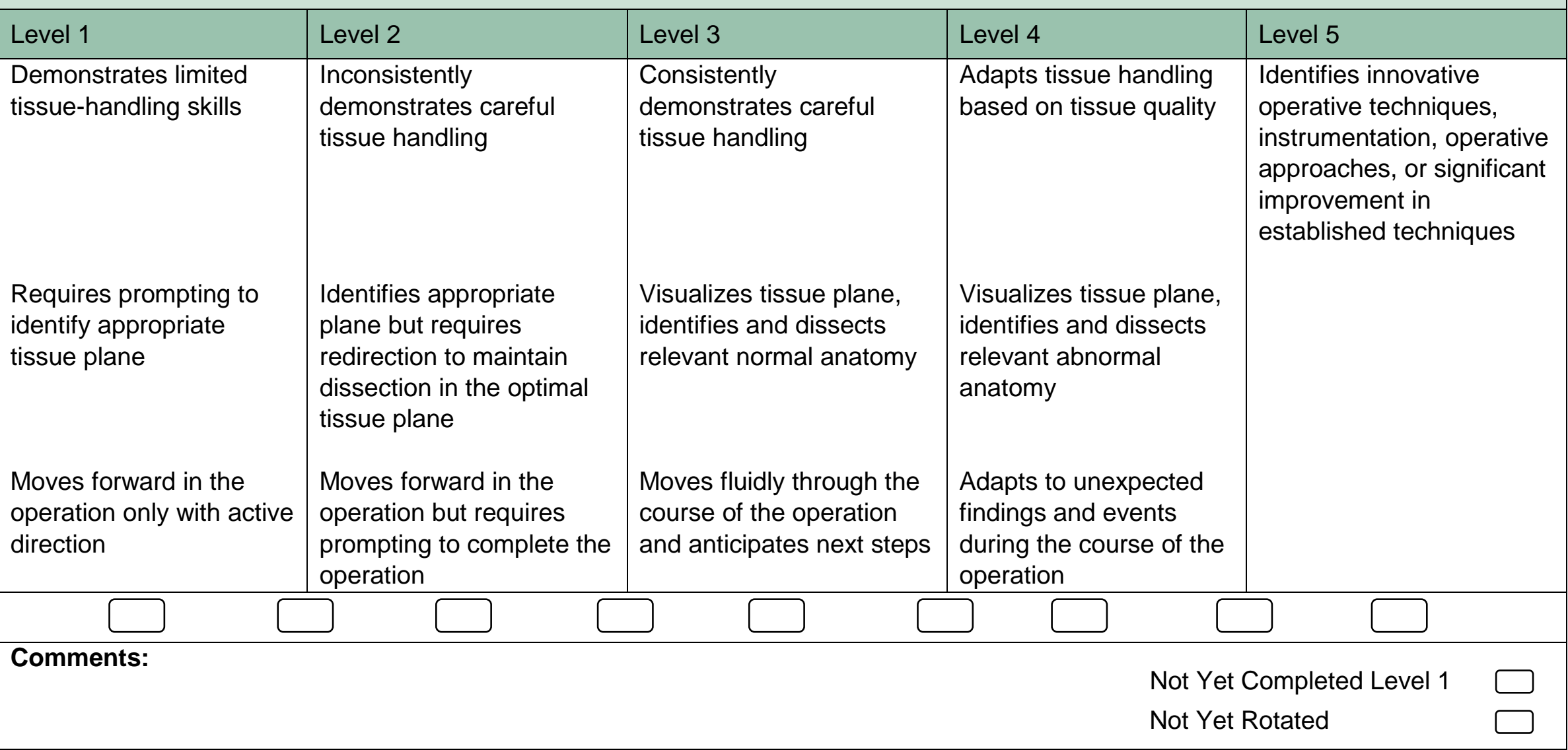




\section{Patient Care 4: Post-Operative Patient Care}

\begin{tabular}{|c|c|c|c|c|}
\hline Level 1 & Level 2 & Level 3 & Level 4 & Level 5 \\
\hline $\begin{array}{l}\text { Evaluates simple post- } \\
\text { operative problems (e.g., } \\
\text { fever, bleeding, } \\
\text { hypotension, oliguria) }\end{array}$ & $\begin{array}{l}\text { Evaluates complex post- } \\
\text { operative problems (e.g., } \\
\text { sepsis, anastomotic leak) }\end{array}$ & $\begin{array}{l}\text { Evaluates complex post- } \\
\text { operative problems in } \\
\text { patient with complex } \\
\text { conditions (e.g., renal } \\
\text { failure, congestive heart } \\
\text { failure cirrhosis) }\end{array}$ & $\begin{array}{l}\text { Anticipates and } \\
\text { mitigates post-operative } \\
\text { problems in patient with } \\
\text { complex conditions }\end{array}$ & $\begin{array}{l}\text { Develops a clinical } \\
\text { pathway or guideline for } \\
\text { management of complex } \\
\text { post-operative problems }\end{array}$ \\
\hline & & & & \\
\hline Comments: & & & \multicolumn{2}{|c|}{$\begin{array}{l}\text { Not Yet Completed Level } 1 \\
\text { Not Yet Rotated }\end{array}$} \\
\hline
\end{tabular}




\section{Medical Knowledge 1: Pathophysiology and Treatment}

\begin{tabular}{|l|l|l|l|l|}
\hline Level 1 & Level 2 & Level 3 & Level 4 & Level 5 \\
\hline $\begin{array}{l}\text { kemonstrates } \\
\text { pathophysiology and } \\
\text { treatments of patients } \\
\text { with common surgical } \\
\text { conditions }\end{array}$ & $\begin{array}{l}\text { Demonstrates knowledge } \\
\text { of pathophysiology and } \\
\text { treatments of patients with } \\
\text { complex surgical } \\
\text { conditions }\end{array}$ & $\begin{array}{l}\text { Demonstrates knowledge } \\
\text { of the impact of patient } \\
\text { factors on } \\
\text { pathophysiology and the } \\
\text { treatment of patients with } \\
\text { surgical conditions }\end{array}$ & $\begin{array}{l}\text { Demonstrates } \\
\text { comprehensive } \\
\text { knowledge of the } \\
\text { varying patterns of } \\
\text { disease presentation } \\
\text { and alternative and } \\
\text { adjuvant treatments of } \\
\text { patients with surgical } \\
\text { conditions }\end{array}$ & $\begin{array}{l}\text { Contributes to peer- } \\
\text { reviewed literature on the } \\
\text { varying patterns of } \\
\text { disease presentation, and } \\
\text { alternative and adjuvant } \\
\text { treatments of patients with } \\
\text { surgical conditions }\end{array}$ \\
\hline Comments:
\end{tabular}




\section{Medical Knowledge 2: Anatomy}

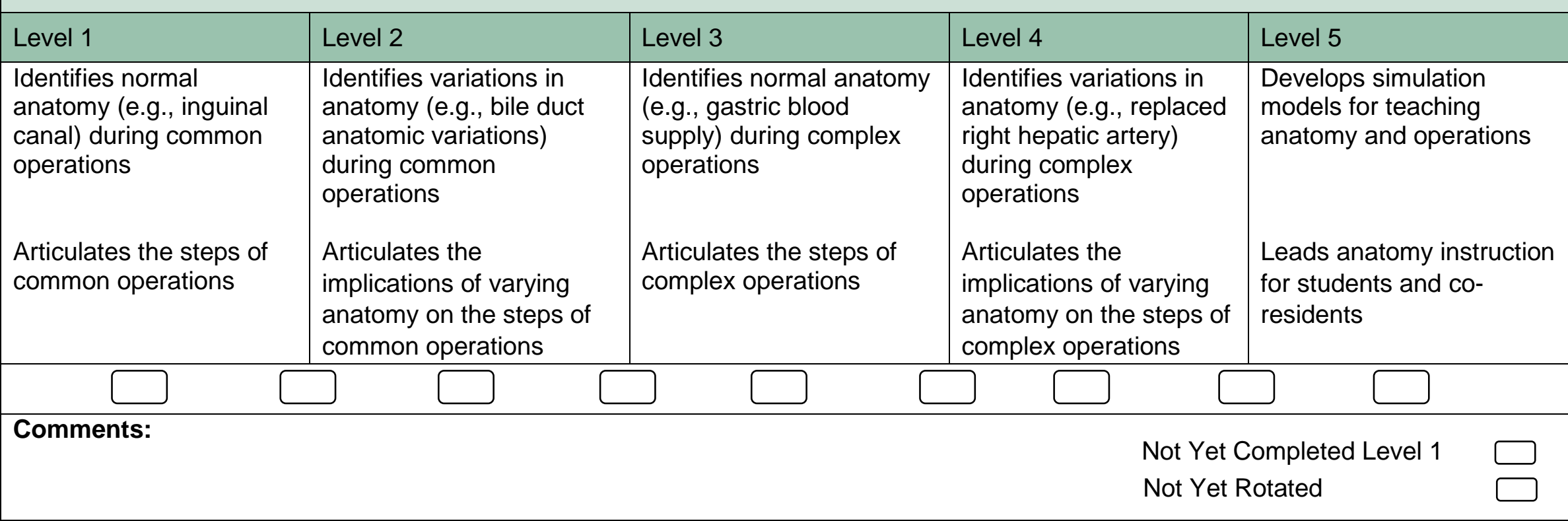




\section{Systems-Based Practice 1: Patient Safety and Quality Improvement}

\begin{tabular}{|c|c|c|c|c|}
\hline Level 1 & Level 2 & Level 3 & Level 4 & Level 5 \\
\hline $\begin{array}{l}\text { Demonstrates } \\
\text { knowledge of common } \\
\text { patient safety events }\end{array}$ & $\begin{array}{l}\text { Identifies system factors } \\
\text { that lead to patient safety } \\
\text { events }\end{array}$ & $\begin{array}{l}\text { Participates in analysis of } \\
\text { patient safety events } \\
\text { (simulated or actual) }\end{array}$ & $\begin{array}{l}\text { Conducts analysis of } \\
\text { patient safety events } \\
\text { and offers error } \\
\text { prevention strategies } \\
\text { (simulated or actual) }\end{array}$ & $\begin{array}{l}\text { Actively engages teams } \\
\text { and processes to modify } \\
\text { systems to prevent patient } \\
\text { safety events }\end{array}$ \\
\hline $\begin{array}{l}\text { Demonstrates } \\
\text { knowledge of how to } \\
\text { report patient safety } \\
\text { events }\end{array}$ & $\begin{array}{l}\text { Reports patient safety } \\
\text { events through } \\
\text { institutional reporting } \\
\text { systems (simulated or } \\
\text { actual) }\end{array}$ & $\begin{array}{l}\text { Participates in disclosure } \\
\text { of patient safety events to } \\
\text { patients and families } \\
\text { (simulated or actual) }\end{array}$ & $\begin{array}{l}\text { Discloses patient safety } \\
\text { events to patients and } \\
\text { families (simulated or } \\
\text { actual) }\end{array}$ & $\begin{array}{l}\text { Mentors others in the } \\
\text { disclosure of patient } \\
\text { safety events }\end{array}$ \\
\hline $\begin{array}{l}\text { Demonstrates } \\
\text { knowledge of basic } \\
\text { quality improvement } \\
\text { methodologies and } \\
\text { metrics }\end{array}$ & $\begin{array}{l}\text { Describes local quality } \\
\text { improvement initiatives } \\
\text { (e.g., infection rate, hand } \\
\text { hygiene, opioid use) }\end{array}$ & $\begin{array}{l}\text { Participates in local } \\
\text { quality improvement } \\
\text { initiatives }\end{array}$ & $\begin{array}{l}\text { Demonstrates the skills } \\
\text { required to identify, } \\
\text { develop, implement, } \\
\text { and analyze a quality } \\
\text { improvement project }\end{array}$ & $\begin{array}{l}\text { Creates, implements, and } \\
\text { assesses quality } \\
\text { improvement initiatives at } \\
\text { the institutional or } \\
\text { community level }\end{array}$ \\
\hline
\end{tabular}

Not Yet Completed Level 1 


\section{Systems-Based Practice 2: System Navigation for Patient-Centered Care}

\begin{tabular}{|l|l|l|l|l|}
\hline Level 1 & Level 2 & Level 3 & Level 4 & Level 5 \\
$\begin{array}{l}\text { Demonstrates } \\
\text { coordination }\end{array}$ & $\begin{array}{l}\text { Coordinates } \\
\text { multidisciplinary care of } \\
\text { patients in routine clinical } \\
\text { situations (e.g., dressing } \\
\text { change) }\end{array}$ & $\begin{array}{l}\text { Coordinates and/or leads } \\
\text { multidisciplinary care of } \\
\text { patients in complex } \\
\text { clinical situations (e.g., } \\
\text { home parenteral nutrition, } \\
\text { postoperative intravenous } \\
\text { feeding, intensive care } \\
\text { unit) }\end{array}$ & $\begin{array}{l}\text { Coordinates care of } \\
\text { patients with barriers to } \\
\text { health care access } \\
\text { (e.g., trauma patient } \\
\text { with no access to care) } \\
\text { or other disparities in } \\
\text { care }\end{array}$ & $\begin{array}{l}\text { Leads in the design and } \\
\text { implementation of } \\
\text { improvements to care } \\
\text { coordination }\end{array}$ \\
$\begin{array}{l}\text { Performs safe and } \\
\text { effective transitions of } \\
\text { care/hand-offs in routine } \\
\text { clinical situations }\end{array}$ & $\begin{array}{l}\text { Performs safe and } \\
\text { effective transitions of } \\
\text { care/hand-offs in complex } \\
\text { clinical situations }\end{array}$ & $\begin{array}{l}\text { Supervises safe and } \\
\text { effective transitions of } \\
\text { care/hand-offs of junior } \\
\text { residents }\end{array}$ & $\begin{array}{l}\text { Resolves conflicts in } \\
\text { transitions of care } \\
\text { between teams }\end{array}$ & $\begin{array}{l}\text { Leads in the design and } \\
\text { implementation of } \\
\text { improvements to } \\
\text { transitions of care }\end{array}$ \\
\hline
\end{tabular}

Comments:

Not Yet Completed Level 1 


\section{Systems-Based Practice 3: Physician Role in Health Care Systems}

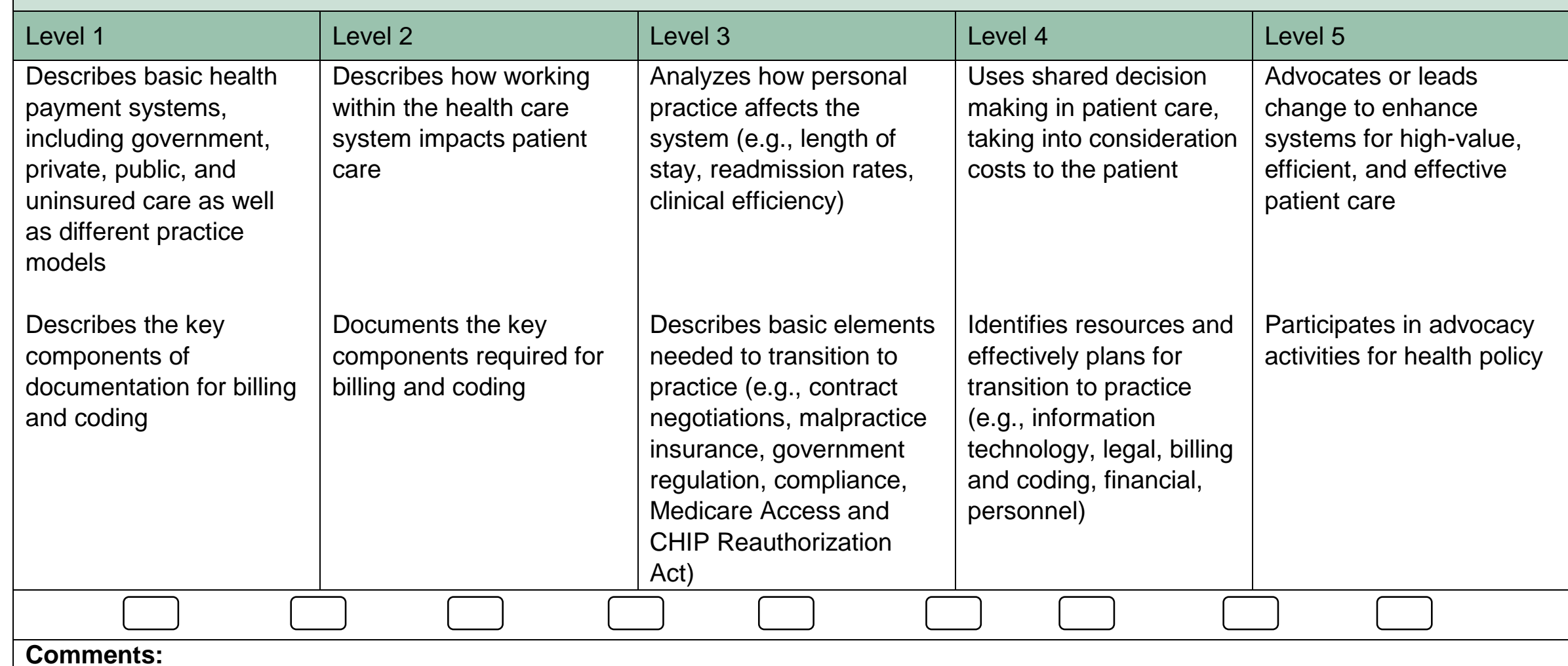

Not Yet Completed Level 1 


\section{Practice-Based Learning and Improvement 1: Evidence-Based and Informed Practice}

\begin{tabular}{|l|l|l|l|l|} 
Level 1 & Level 2 & Level 3 & Level 4 & Level 5 \\
\hline $\begin{array}{l}\text { Demonstrates how to } \\
\text { access and use available } \\
\text { evidence, and } \\
\text { incorporate patient } \\
\text { preferences and values } \\
\begin{array}{l}\text { into the care of patients } \\
\text { with routine conditions }\end{array}\end{array}$ & $\begin{array}{l}\text { Articulates clinical } \\
\text { questions and elicits } \\
\text { patient preferences and } \\
\text { values in order to guide } \\
\text { evidence-based care }\end{array}$ & $\begin{array}{l}\text { Locates and applies the } \\
\text { best available evidence, } \\
\text { integrated with patient } \\
\text { preference, to the care of } \\
\text { patients with complex } \\
\text { conditions }\end{array}$ & $\begin{array}{l}\text { Critically appraises and } \\
\text { applies evidence, even } \\
\text { in the face of uncertain } \\
\text { and/or conflicting } \\
\text { evidence, to guide care, } \\
\text { tailored to the individual } \\
\text { patient }\end{array}$ & $\begin{array}{l}\text { Coaches others to } \\
\text { critically appraise and } \\
\text { apply evidence for } \\
\text { patients with complex } \\
\text { conditions; and/or } \\
\text { participates in the } \\
\text { development of guidelines }\end{array}$ \\
\hline
\end{tabular}

Comments:

Not Yet Completed Level 1 


\section{Practice-Based Learning and Improvement 2: Reflective Practice and Commitment to Personal Growth}

\begin{tabular}{|l|l|l|l|l|} 
Level 1 & Level 2 & Level 3 & Level 4 & Level 5 \\
$\begin{array}{l}\text { Establishes goals for } \\
\text { personal and } \\
\text { professional } \\
\text { development }\end{array}$ & $\begin{array}{l}\text { Identifies opportunities for } \\
\text { performance } \\
\text { improvement; designs a } \\
\text { learning plan }\end{array}$ & $\begin{array}{l}\text { Integrates performance } \\
\text { feedback and practice } \\
\text { data to develop and } \\
\text { implement a learning plan }\end{array}$ & $\begin{array}{l}\text { Revises learning plan } \\
\text { based on performance } \\
\text { data }\end{array}$ & $\begin{array}{l}\text { Coaches others in the } \\
\text { design and } \\
\text { implementation of } \\
\text { learning plans }\end{array}$
\end{tabular}

\section{Comments:}




\section{Professionalism 1: Ethical Principles}

\begin{tabular}{|c|c|c|c|c|}
\hline Level 1 & Level 2 & Level 3 & Level 4 & Level 5 \\
\hline $\begin{array}{l}\text { Demonstrates } \\
\text { knowledge of the ethical } \\
\text { principles underlying } \\
\text { informed consent, } \\
\text { surrogate decision } \\
\text { making, advance } \\
\text { directives, confidentiality, } \\
\text { error disclosure, } \\
\text { stewardship of limited } \\
\text { resources, and related } \\
\text { topics }\end{array}$ & $\begin{array}{l}\text { Analyzes straightforward } \\
\text { situations using ethical } \\
\text { principles }\end{array}$ & $\begin{array}{l}\text { Recognizes need to seek } \\
\text { help in managing and } \\
\text { resolving complex ethical } \\
\text { situations }\end{array}$ & $\begin{array}{l}\text { Recognizes and uses } \\
\text { appropriate resources } \\
\text { for managing and } \\
\text { resolving ethical } \\
\text { dilemmas, as needed } \\
\text { (e.g., ethics } \\
\text { consultations, literature } \\
\text { review, risk } \\
\text { management/legal } \\
\text { consultation) }\end{array}$ & $\begin{array}{l}\text { Identifies and seeks to } \\
\text { address system-level } \\
\text { factors that induce or } \\
\text { exacerbate ethical } \\
\text { problems or impede their } \\
\text { resolution }\end{array}$ \\
\hline
\end{tabular}

Not Yet Completed Level 1 


\section{Professionalism 2: Professional Behavior and Accountability}

\begin{tabular}{|c|c|c|c|c|}
\hline Level 1 & Level 2 & Level 3 & Level 4 & Level 5 \\
\hline $\begin{array}{l}\text { Completes patient care } \\
\text { tasks and } \\
\text { responsibilities, identifies } \\
\text { potential barriers, and } \\
\text { describes strategies for } \\
\text { ensuring timely task } \\
\text { completion }\end{array}$ & $\begin{array}{l}\text { Performs patient care } \\
\text { tasks and responsibilities } \\
\text { in a timely manner with } \\
\text { appropriate attention to } \\
\text { detail in routine situations }\end{array}$ & $\begin{array}{l}\text { Performs patient care } \\
\text { tasks and responsibilities } \\
\text { in a timely manner with } \\
\text { appropriate attention to } \\
\text { detail in complex or } \\
\text { stressful situations }\end{array}$ & $\begin{array}{l}\text { Recognizes situations } \\
\text { that may impact others' } \\
\text { ability to complete } \\
\text { patient-care tasks and } \\
\text { responsibilities in a } \\
\text { timely manner }\end{array}$ & $\begin{array}{l}\text { Develops systems to } \\
\text { enhance other's ability to } \\
\text { efficiently complete } \\
\text { patient-care tasks and } \\
\text { responsibilities }\end{array}$ \\
\hline & & & $\begin{array}{l}\text { Appropriately reports } \\
\text { lapses in professional } \\
\text { behavior (simulated or } \\
\text { actual) }\end{array}$ & \\
\hline $\begin{array}{l}\text { Recognizes limits in the } \\
\text { knowledge/skills of self } \\
\text { and seeks help }\end{array}$ & $\begin{array}{l}\text { Recognizes limits in the } \\
\text { knowledge/skills of team } \\
\text { and seeks help }\end{array}$ & $\begin{array}{l}\text { Exhibits appropriate } \\
\text { confidence and self- } \\
\text { awareness of limits in } \\
\text { knowledge/skills }\end{array}$ & $\begin{array}{l}\text { Aids junior learners in } \\
\text { recognition of limits in } \\
\text { knowledge/skills }\end{array}$ & \\
\hline
\end{tabular}

Comments: 


\section{Professionalism 3: Administrative Tasks}

\begin{tabular}{|c|c|c|c|c|}
\hline Level 1 & Level 2 & Level 3 & Level 4 & Level 5 \\
\hline $\begin{array}{l}\text { Takes responsibility for } \\
\text { failure to complete } \\
\text { administrative tasks and } \\
\text { responsibilities, identifies } \\
\text { potential contributing } \\
\text { factors, and describes } \\
\text { strategies for ensuring } \\
\text { timely task completion in } \\
\text { the future }\end{array}$ & $\begin{array}{l}\text { Performs administrative } \\
\text { tasks and responsibilities } \\
\text { in a timely manner with } \\
\text { appropriate attention to } \\
\text { detail in routine situations }\end{array}$ & $\begin{array}{l}\text { Performs administrative } \\
\text { tasks and responsibilities } \\
\text { in a timely manner with } \\
\text { appropriate attention to } \\
\text { detail in complex or } \\
\text { stressful situations }\end{array}$ & $\begin{array}{l}\text { Recognizes situations } \\
\text { that may impact others' } \\
\text { ability to complete } \\
\text { administrative tasks and } \\
\text { responsibilities in a } \\
\text { timely manner }\end{array}$ & $\begin{array}{l}\text { Develops systems to } \\
\text { enhance other's ability to } \\
\text { efficiently complete } \\
\text { administrative tasks and } \\
\text { responsibilities }\end{array}$ \\
\hline
\end{tabular}

\section{Comments:}




\section{Professionalism 4: Self-Awareness and Help-Seeking}

\begin{tabular}{|c|c|c|c|c|}
\hline Level 1 & Level 2 & Level 3 & Level 4 & Level 5 \\
\hline $\begin{array}{l}\text { Identifies the institutional } \\
\text { resources available to } \\
\text { manage personal, } \\
\text { physical, and emotional } \\
\text { health (e.g., acute and } \\
\text { chronic disease, } \\
\text { substance abuse, and } \\
\text { mental health problems) }\end{array}$ & $\begin{array}{l}\text { Monitors his or her own } \\
\text { personal health and } \\
\text { wellness and } \\
\text { appropriately mitigates } \\
\text { fatigue and/or stress }\end{array}$ & $\begin{array}{l}\text { Promotes healthy habits } \\
\text { and creates an } \\
\text { emotionally healthy } \\
\text { environment for } \\
\text { colleagues }\end{array}$ & $\begin{array}{l}\text { Recognizes and } \\
\text { appropriately addresses } \\
\text { signs and symptoms of } \\
\text { burnout, depression, } \\
\text { suicidal ideation, } \\
\text { potential for violence, } \\
\text { and/or substance abuse } \\
\text { in other members of the } \\
\text { health care team }\end{array}$ & $\begin{array}{l}\text { Coaches others when } \\
\text { emotional responses or } \\
\text { limitations in } \\
\text { knowledge/skills do not } \\
\text { meet professional } \\
\text { expectations }\end{array}$ \\
\hline $\begin{array}{l}\text { Demonstrates } \\
\text { knowledge of the } \\
\text { principles of physician } \\
\text { well-being and fatigue } \\
\text { mitigation }\end{array}$ & $\begin{array}{l}\text { Manages his or her own } \\
\text { time and assures fitness } \\
\text { for duty }\end{array}$ & $\begin{array}{l}\text { Models appropriate } \\
\text { management of personal } \\
\text { health issues, fatigue, and } \\
\text { stress }\end{array}$ & $\begin{array}{l}\text { Proactively modifies } \\
\text { schedules or intervenes } \\
\text { in other ways to assure } \\
\text { that those caregivers } \\
\text { under his or her } \\
\text { supervision maintain } \\
\text { personal wellness and } \\
\text { do not compromise } \\
\text { patient safety (e.g., } \\
\text { requires naps, counsels, } \\
\text { refers to services, } \\
\text { reports to program } \\
\text { director) }\end{array}$ & \\
\hline
\end{tabular}

Comments:

Not Yet Completed Level 1 


\section{Interpersonal and Communication Skills 1: Patient and Family-Centered Communication}

\begin{tabular}{|l|l|l|l|l|}
\hline Level 1 & Level 2 & Level 3 & Level 4 & Level 5 \\
\hline $\begin{array}{l}\text { Communicates with } \\
\text { patients and their } \\
\text { families in an } \\
\text { understandable and } \\
\text { respectful manner }\end{array}$ & $\begin{array}{l}\text { Customizes } \\
\text { communication, in the } \\
\text { setting of personal biases } \\
\text { and barriers (e.g., age, } \\
\text { literacy, cognitive } \\
\text { disabilities, cultural } \\
\text { differences) with patients } \\
\text { and families }\end{array}$ & $\begin{array}{l}\text { Delivers complex and } \\
\text { difficult information to } \\
\text { patients and families }\end{array}$ & $\begin{array}{l}\text { Facilitates difficult } \\
\text { discussions specific to } \\
\text { patient and family } \\
\text { conferences, (e.g., end- } \\
\text { of-life, explaining } \\
\text { complications, } \\
\text { therapeutic uncertainty) }\end{array}$ & $\begin{array}{l}\text { Coaches others in the } \\
\text { facilitation of crucial } \\
\text { conversations }\end{array}$ \\
$\begin{array}{l}\text { Provides timely updates } \\
\text { to patients and families } \\
\text { Actively listens to patients } \\
\text { and families to elicit } \\
\text { patient preferences and } \\
\text { expectations }\end{array}$ & $\begin{array}{l}\text { Uses shared decision } \\
\text { making to make a } \\
\text { personalized care plan }\end{array}$ & $\begin{array}{l}\text { Effectively negotiates } \\
\text { and manages conflict } \\
\text { among patients, } \\
\text { families, and the health } \\
\text { care team }\end{array}$ & $\begin{array}{l}\text { Coaches others in conflict } \\
\text { resolution }\end{array}$ \\
\hline Comments:
\end{tabular}

Not Yet Completed Level 1 


\section{Interpersonal and Communication Skills 2: Interprofessional and Team Communication}

\begin{tabular}{|c|c|c|c|c|}
\hline Level 1 & Level 2 & Level 3 & Level 4 & Level 5 \\
\hline $\begin{array}{l}\text { Respectfully requests } \\
\text { and receives a } \\
\text { consultation }\end{array}$ & $\begin{array}{l}\text { Clearly and concisely } \\
\text { requests and responds to } \\
\text { a consultation }\end{array}$ & $\begin{array}{l}\text { Verifies understanding of } \\
\text { recommendations when } \\
\text { providing or receiving a } \\
\text { consultation }\end{array}$ & $\begin{array}{l}\text { Coordinates } \\
\text { recommendations from } \\
\text { different members of the } \\
\text { health care team to } \\
\text { optimize patient care, } \\
\text { resolving conflict when } \\
\text { needed }\end{array}$ & $\begin{array}{l}\text { Coaches flexible } \\
\text { communication strategies } \\
\text { that value input from all } \\
\text { health care team } \\
\text { members }\end{array}$ \\
\hline \multirow[t]{2}{*}{$\begin{array}{l}\text { Uses language that } \\
\text { values all members of } \\
\text { the health care team }\end{array}$} & $\begin{array}{l}\text { Communicates } \\
\text { information effectively } \\
\text { with all health care team } \\
\text { members }\end{array}$ & $\begin{array}{l}\text { Uses active listening to } \\
\text { adapt communication } \\
\text { style to fit team needs }\end{array}$ & $\begin{array}{l}\text { Maintains effective } \\
\text { communication in crisis } \\
\text { situation }\end{array}$ & \\
\hline & $\begin{array}{l}\text { Solicits feedback on } \\
\text { performance as a } \\
\text { member of the health care } \\
\text { team }\end{array}$ & $\begin{array}{l}\text { Communicates concerns } \\
\text { and provides feedback to } \\
\text { peers and learners }\end{array}$ & $\begin{array}{l}\text { Communicates } \\
\text { constructive feedback to } \\
\text { superiors }\end{array}$ & $\begin{array}{l}\text { Facilitates regular health } \\
\text { care team-based } \\
\text { feedback in complex } \\
\text { situations }\end{array}$ \\
\hline & & & & \\
\hline
\end{tabular}

Not Yet Completed Level 1 


\section{Interpersonal and Communication Skills 3: Communication within Health Care Systems}

\begin{tabular}{|l|l|l|l|l|}
\hline Level 1 & Level 2 & Level 3 & Level 4 & Level 5 \\
\hline $\begin{array}{l}\text { Accurately records } \\
\text { information in the patient } \\
\text { record, including } \\
\begin{array}{l}\text { appropriate use of } \\
\text { documentation templates }\end{array}\end{array}$ & $\begin{array}{l}\text { Demonstrates efficient } \\
\text { use of electronic medical } \\
\text { record to communicate } \\
\text { with the health care team }\end{array}$ & $\begin{array}{l}\text { Integrates and } \\
\text { synthesizes all relevant } \\
\text { data from outside systems } \\
\text { and prior encounters into } \\
\text { the health record }\end{array}$ & $\begin{array}{l}\text { Appropriately selects } \\
\text { form and urgency of } \\
\text { communication based } \\
\text { on context }\end{array}$ & $\begin{array}{l}\text { Guides departmental or } \\
\text { institutional } \\
\text { communication around } \\
\text { policies and procedures }\end{array}$ \\
\hline
\end{tabular}

\section{Comments:}

